\title{
Miejsce i znaczenie AOTMiT w polskim systemie ochrony zdrowia
}

\author{
Aneta Lipińska ${ }^{1}$ \\ Tomasz Nawrocki ${ }^{1}$ \\ Monika Patyna ${ }^{2}$
}

Aneta Płusa ${ }^{1}$

Maciej Pomorski ${ }^{1}$

Anna Ziębińska ${ }^{1}$

\footnotetext{
${ }^{1}$ Dział Analiz i Strategii, Agencja Oceny Technologii Medycznych i Taryfikacji

${ }^{2}$ Biuro Prezesa, Agencja Oceny Technologii Medycznych i Taryfikacji
}

Adres do korespondencji: Aneta Lipińska, Dział Analiz i Strategii, Agencja Oceny Technologii Medycznych i Taryfikacji, ul. Przeskok 2, 00-032 Warszawa, sekretariat@aotm.gov.pl

\section{Abstract}

\section{Agency for Health Technology Assessment and Tariff System in health care system in Poland}

The Agency for Health Technology Assessment and Tariff System is national institution supervised by Minister of Health and funded by government. Agency is an advisory body in the reimbursement process. Agency has an impact on content of benefit basket, not only by evaluating new technologies but also re-evaluating benefit basket. Main goal of Agency is to provide patients access to the most effective and safe technologies. The most important Agency statements concern medical technologies and its modifications, qualification, removal in reference to guaranteed medical services. The Minister of Health, taking decisions about which health technology should be financed by public found, takes into account: recommendations and opinions of President of Agency, opinions and statements of the Transparency Council and the Council for Tariffs Affairs. The Agency's task is also: setting tariffs for health care services; evaluating diagnostic and therapeutic guidelines prepared by medical societies; preparing opinions about national and local government health care programs.

Key words: HTA, medical service, reimbursement, tariffs

Stowa kluczowe: HTA, świalczenie, refundacja, taryfikacja

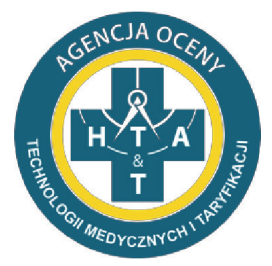

\section{AGENCJA OCENY TECHNOLOGII MEDYCZNYCH I TARYFIKACJI}

\section{Historia i struktura organizacyjna AOTMiT}

Agencja Oceny Technologii Medycznych została utworzona 16 września 2005 roku na podstawie Zarządzenia Ministra Zdrowia z dnia 1 września 2005 roku w sprawie utworzenia Agencji Oceny Technologii Medycznych

\section{Rzeczpospolita Polska \\ Unia Europejska
Fundusz Spójności

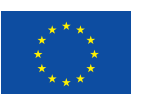

(Dz.Urz. MZ z 2005 roku Nr 13 poz. 56) jako państwowej jednostki budżetowej podległej ministrowi właściwemu do spraw zdrowia. Zadaniem agencji było dokonywanie oceny procedur medycznych, ze szczególnym uwzględnieniem procedur medycznych będących przedmiotem umów o udzielanie świadczeń opieki zdrowotnej. 
Na mocy Ustawy z dnia 25 czerwca 2009 roku o zmianie ustawy o świadczeniach opieki zdrowotnej finansowanych ze środków publicznych oraz ustawy o cenach (Dz.U. z 2009 roku Nr 118 poz. 989) Agencja Oceny Technologii Medycznych uzyskała status państwowej jednostki organizacyjnej posiadającej osobowość prawną.

$\mathrm{Na}$ podstawie Ustawy z dnia 22 lipca 2014 roku o zmianie ustawy o świadczeniach opieki zdrowotnej finansowanych ze środków publicznych z dnia 1 stycznia 2015 roku agencja otrzymała kolejne zadania dotyczące taryfikacji świadczeń opieki zdrowotnej. Nowelizacja ustawy wprowadziła zmianę nazwy Agencji Oceny Technologii Medycznych na Agencję Oceny Technologii Medycznych i Taryfikacji (AOTMiT). Zmianie uległa również struktura organizacyjna agencji, która odzwierciedliła dwie główne dziedziny działalności: ocenę technologii medycznych i wycenę świadczeń gwarantowanych.

Wskutek kolejnych nowelizacji aktów prawnych zakres zadań agencji i jej uprawnienia uległy dalszemu poszerzeniu w ramach wskazanych wyżej dwóch dziedzin.

$\mathrm{Na}$ czele agencji stoi prezes. Obecnie agencja składa się z dziesięciu komórek organizacyjnych: Biura Prezesa, Biura Kadr, Biura Księgowości, Biura Prawnego, Wydziału Świadczeń Opieki Zdrowotnej, Wydziału Oceny Technologii Medycznych, Wydziału Taryfikacji, Wydziału Informatyki, Samodzielnego Stanowiska Pracy Rzecznika Prasowego i Samodzielnego Stanowiska Pracy do spraw Audytu Wewnętrznego. W ramach komórek organizacyjnych AOTMiT wydzielone przez prezesa agencji zespoły mogą wykonywać zadania poza jej siedzibą.

\section{Aspekty prawne funkcjonowania AOTMiT}

AOTMiT funkcjonuje w ściśle regulowanym prawem środowisku. Strukturę agencji określa statut, który jest nadawany i zmieniany rozporządzeniem ministra właściwego do spraw zdrowia. Finanse agencji i sposób prowadzenia księgowości również podlegają regulacjom ustawowym.

Funkcjonowanie AOTMiT, a w szczególności jej zadania i uprawnienia, regulują dwa podstawowe akty prawne:

- Ustawa z dnia 27 sierpnia 2004 roku o świadczeniach opieki zdrowotnej finansowanych ze środków publicznych (dalej: ust. o św.) (Dz.U. z 2018 roku poz. 1510 z późn. zm.) [1];

- Ustawa z dnia 12 maja 2011 roku o refundacji leków, środków spożywczych specjalnego przeznaczenia żywieniowego oraz wyrobów medycznych (dalej: ust. o ref.) (Dz.U. z 2017 roku poz. 1844 z późn. zm.) [2]. Najważniejsze zapisy ust. o św. obejmują:

- art. 11 ust. 1 pkt 10 i 11 - nadzór oraz zatwierdzanie sprawozdań przez ministra właściwego do spraw zdrowia;

- art. 11 ust. 3 - wydawanie opinii agencji do zaleceń postępowania diagnostyczno-terapeutycznego w zakresie świadczeń finansowanych ze środków publicznych w chorobach nowotworowych;
- $\quad$ art. 31a ust. 1 - kryteria oceny podstawy do kwalifikacji świadczeń opieki zdrowotnej jako świadczenia gwarantowanego;

- art. 31c - przygotowanie rekomendacji w sprawie kwalifikacji świadczenia jako świadczenia gwarantowanego oraz określenie poziomu lub sposobu finansowania;

- art. 31ca - przygotowanie rekomendacji w sprawie zasadności stosowania leków w ramach Programu Szczepień Ochronnych;

- art. 31e - przygotowanie rekomendacji w sprawie usunięcia świadczenia z wykazu świadczeń gwarantowanych, zmiany poziomu lub sposobu finansowania świadczeń gwarantowanych oraz zmiany technologii medycznej;

- art. 31la - sporządzanie projektu planu taryfikacji przez AOTMiT;

- art. 31lb - określanie taryfy świadczeń w danym zakresie lub rodzaju;

- $\quad$ art. $31 \mathrm{~m}$ - funkcjonowanie AOTMiT;

- $\quad$ art. 31n-zadania AOTMiT;

- art. 31o-prezes AOTMiT;

- $\quad$ art. $31 \mathrm{p}$ - sposób powoływania prezesa AOTMiT;

- $\quad$ art. 31s - Rada Przejrzystości działająca przy prezesie AOTMiT pełniąca funkcję opiniodawczo-doradczą;

- art. 31sa - Rada do spraw Taryfikacji działająca przy prezesie AOTMiT pełniąca funkcję opiniodawczo-doradczą;

- art. 47d - opinie w sprawie Ratunkowego Dostępu do Technologii Lekowych (RDTL);

- art. 48a - opinie w sprawie Programów Polityki Zdrowotnej;

- art. 48aa - rekomendacje w sprawie zalecanych technologii medycznych, działań przeprowadzanych w ramach programów polityki zdrowotnej oraz warunków realizacji tych programów, dotyczących danej choroby lub danego problemu zdrowotnego Najważniejsze zapisy ust. o ref. obejmują:

- $\quad$ art. 13 - ustalenie urzędowej ceny zbytu leku, środka spożywczego specjalnego przeznaczenia żywieniowego (ŚSSPŻ), wyrobu medycznego (WM), dla którego żaden odpowiedni nie jest refundowany $\mathrm{w}$ danym wskazaniu;

- art. 35 - proces decyzyjny odnoszący się do refundacji leku, środka spożywczego specjalnego przeznaczenia żywieniowego, wyrobu medycznego;

- $\quad$ art. 39 - proces decyzyjny odnoszący się do refundacji produktu sprowadzanego z zagranicy w ramach importu docelowego.

\section{Organy opiniodawczo-doradcze}

Przy prezesie agencji działają dwa organy opiniodawczo-doradcze: Rada Przejrzystości oraz Rada do spraw Taryfikacji. Członków rad powołuje minister zdrowia, a kadencja trwa sześć lat.

\section{Rada Przejrzystości}

Zgodnie z ust. o św. w skład Rady Przejrzystości (RP) wchodzi: czterech przedstawicieli ministra zdrowia, 
dwóch przedstawicieli prezesa Narodowego Funduszu Zdrowia, dwóch przedstawicieli prezesa Urzędu Rejestracji Produktów Leczniczych, Wyrobów Medycznych i Produktów Biobójczych, dwóch przedstawicieli Rzecznika Praw Pacjenta i dziesięć osób posiadających doświadczenie, uznany dorobek oraz co najmniej stopień naukowy doktora nauk medycznych lub dziedzin pokrewnych, lub innych dziedzin odpowiednich do przeprowadzenia oceny świadczeń opieki zdrowotnej, w tym etyki.

Do zadań RP (art. 31s ust. 6 ust. o św.) należy:

- przygotowywanie i przedstawianie stanowisk w sprawie kwalifikacji świadczeń jako gwarantowanych, zmiany poziomu/sposobu finansowania świadczeń/ technologii medycznych (w tym import docelowy), usunięcia świadczenia gwarantowanego z koszyka, zmiany technologii medycznych, zasadności objęcia refundacją leku, ŚSSPŻ, WM;

- wydawanie opinii: o projektach programów polityki zdrowotnej, w sprawie zalecanych technologii medycznych, działań przeprowadzanych w ramach programów polityki zdrowotnej oraz warunków realizacji tych programów, dotyczących danej choroby lub danego problemu zdrowotnego;

- realizacja innych zadań zleconych przez prezesa AOTMiT.

Do samodzielnych zadań rady - na zlecenie ministra zdrowia należy wydawanie opinii w zakresie: zasadności utworzenia wspólnej/odrębnej grupy limitowej (art. 15 ust. o ref.); uchylenia decyzji o objęciu refundacją leku, ŚSSPŻ, WM (art. 33 ust. o ref.); zasadności objęcia refundacją substancji czynnej we wskazaniach pozarejestracyjnych (art. 40 ust. o ref.).

\section{Rada do spraw Taryfikacji}

Zgodnie z ust. o św. w skład Rady do spraw Taryfikacji wchodzi dziesięciu członków powoływanych przez ministra zdrowia, w tym dwóch członków zgłoszonych przez prezesa Narodowego Funduszu Zdrowia. Tryb pracy Rady do spraw Taryfikacji określa regulamin pracy uchwalany przez radę i zatwierdzany przez prezesa AOTMiT.

Do zadań Rady do spraw Taryfikacji (art. 31sa ust. 2 ust. o św.) należy:

- opiniowanie planu taryfikacji i metodyki taryfikacji świadczeń;

- prowadzenie konsultacji w sprawie taryfy;

- wydawanie stanowisk w sprawie ustalenia taryfy świadczeń;

- realizacja innych zadań zleconych przez prezesa AOTMiT.

\section{Instytucje działajace w zakresie ochrony zdrowia w Polsce}

Do najważniejszych instytucji związanych z wydatkowaniem budżetu płatnika publicznego w zakresie ochrony zdrowia w Polsce należą Ministerstwo Zdrowia (MZ) i Narodowy Fundusz Zdrowia (NFZ).
MZ pełni funkcję regulatora i płatnika, definiuje koszyk świadczeń gwarantowanych, finansuje procedury wysokospecjalistyczne czy obligatoryjne szczepienia oraz wdraża narodowe programy zdrowotne.

NFZ pełni funkcję płatnika, planuje i dzieli budżet na poszczególne kategorie świadczeń, zawiera kontrakty ze świadczeniodawcami na udzielanie świadczeń gwarantowanych oraz płaci za zrealizowane świadczenia zdrowotne.

AOTMiT jest natomiast instytucją pełniącą funkcję doradczą, ocenia technologie medyczne, wytyczne kliniczne i programy polityki zdrowotnej, porządkuje koszyk świadczeń gwarantowanych oraz taryfikuje świadczenia.

Proces podejmowania decyzji refundacyjnej w Polsce

m.in.

Firmy farmaceutyczne

Konsultanci krajowi

Prezes NFZ

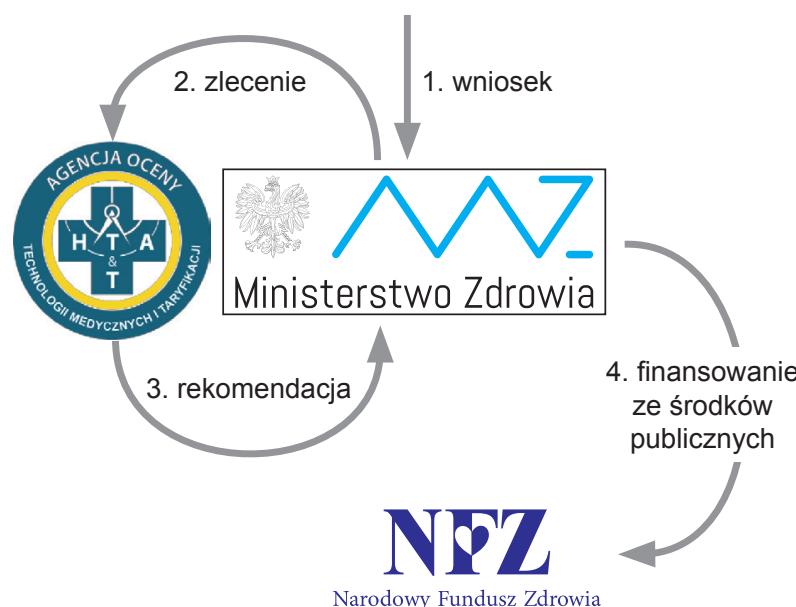

Rysunek 1. Schemat procesu podejmowania decyzji refundacyjnych w Polsce

Źródto: Opracowanie własne AOTMiT.

Miejsce AOTMiT w procesie podejmowania decyzji refundacyjnych w Polsce przedstawiono na Rysunku 1. Podmioty inicjujące proces refundacyjny, uprawnione do składania wniosków o refundację technologii medycznych do ministra zdrowia, to między innymi firmy farmaceutyczne, konsultanci krajowi, prezes NFZ, w zależności od rodzaju wniosku refundacyjnego. W trakcie rozpatrywania wniosku o refundację minister zdrowia obligatoryjnie lub dowolnie przekazuje zlecenie do AOTMiT w sprawie oceny zasadności refundacji technologii medycznych będących przedmiotem wniosku. Końcowym etapem realizacji zlecenia ministra zdrowia w AOTMiT jest wydanie rekomendacji prezesa AOTMiT w sprawie zasadności lub niezasadności refundacji danej technologii medycznej. Ostateczną decyzję o refundacji lub braku refundacji technologii medycznej podejmuje minister zdrowia. Podjęcie pozytywnej decyzji refundacyjnej skutkuje finansowaniem jej ze środków publicznych (NFZ). 


\section{Zadania i działalność}

\section{Ocena technologii medycznych}

Ocena technologii medycznych, zgodnie z międzynarodowymi standardami HTA (ang. Health Technology Assessment), obejmuje dwa odrębne procesy: ocenę analityczną (ang. assessment) oraz ocenę wartościującą (ang. appraisal). Ocena analityczna jest procesem naukowym opartym na systematycznie zebranych, wiarygodnych, najlepszych dostępnych dowodach naukowych. Stanowi ona obiektywną, krytyczną ocenę, przeprowadzoną na podstawie dowodów naukowych oraz wyników analiz, zgodnie z wytycznymi HTA [3], co ma na celu zapewnienie wysokiej jakości i wiarygodności. Celem oceny analitycznej jest udzielenie odpowiedzi na pytania postawione $\mathrm{w}$ ramach poszczególnych analiz. Wyniki analizy klinicznej mają dostarczyć informacji, czy oceniana technologia medyczna wniesie dodatkową korzyść zdrowotną w porównaniu z komparatorem. Wyniki analizy ekonomicznej powinny wskazać, czy koszt uzyskania dodatkowej korzyści $\mathrm{z}$ zastosowaniem technologii jest akceptowalny. Natomiast wyniki analizy wpływu na budżet mają odpowiedzieć na pytanie, jak wprowadzenie finansowania technologii wpłynie na budżet płatnika. Ocena wartościująca dokonywana jest niezależnie od oceny analitycznej i ma na celu wartościowanie wniosków naukowych. Poza dowodami naukowymi bierze również pod uwagę priorytety zdrowotne, skutki następstw choroby, znaczenie dla zdrowia obywateli, preferencje społeczne obywateli/pacjentów, kwestie organizacyjne i prawne oraz aspekty etyczne (leczenie bólu, leki sieroce, opieka paliatywna). Ocena wartościująca jest zawarta w rekomendacjach i opiniach prezesa AOTMiT.

Najważniejsze zadania AOTMiT w zakresie oceny technologii medycznych obejmują:

- wydawanie rekomendacji w sprawie kwalifikacji świadczeń do koszyka (art. 31c ust. o św.);

- wydawanie rekomendacji w sprawie: usunięcia świadczenia z koszyka, zmiany poziomu lub sposobu finansowania lub warunków realizacji świadczenia, zmiany technologii medycznej (art. $31 \mathrm{~h}$ ust. o św.);

- wydawanie opinii w sprawie ratunkowego dostępu do technologii lekowej (art. 47f ust. o św.);

- wydawanie opinii w sprawie programów polityki zdrowotnej (art. 48a ust. o św.);

- wydawanie rekomendacji w sprawie zlecanych technologii medycznych, działań przeprowadzanych w ramach programów polityki zdrowotnej oraz warunków realizacji tych programów, dotyczących danej choroby lub danego problemu zdrowotnego (art. 48aa ust. o św.);

- wydawanie rekomendacji w sprawie objęcia refundacją produktu leczniczego lub ŚSSPŻ (art. 35 ust. 1 ust. o ref.);

- wydawanie rekomendacji w sprawie zasadności wydawania zgody na refundację produktu leczniczego lub ŚSSPŻ w trybie importu docelowego (art. 39 ust. 3 ust. o ref.; art. 31 ust. o św.);
- wydawanie opinii RP w sprawie objęcia refundacją leku we wskazaniu odmiennym niż określonym w ChPL - off-label (art. 40 ust. o ref.);

- inne zlecone zadania, na przykład wydanie opinii czy przygotowanie materiałów analitycznych (art. 31n pkt 5 ust. o św.).

Wyżej wymienione zadania AOTMiT są elementem procesów/postępowań prowadzonych $\mathrm{w}$ ramach systemu ochrony zdrowia w Polsce. Każdy z procesów jest opisany i regulowany za pomocą aktów prawnych i aktów wykonawczych. W zależności od rodzaju procesu/postępowania uczestniczą w nim różne podmioty. Rola AOTMiT w systemie ochrony zdrowia w Polsce uwidacznia się w szczególności na etapie opiniowania i oceny nowych technologii medycznych, rozważanych do włączenia do koszyka świadczeń gwarantowanych oraz zmiany lub usunięcia technologii medycznych już funkcjonujących w systemie. Na podstawie rekomendacji/opinii prezesa agencji, opinii/stanowisk RP/Rady do spraw Taryfikacji i materiałów analitycznych opracowanych przez agencję minister zdrowia, biorąc pod uwagę kryteria wskazane we właściwych aktach prawnych, podejmuje decyzje dotyczące warunków refundacji i finansowania technologii medycznych. AOTMiT wpływa na kształt koszyka świadczeń gwarantowanych w zakresie: kwalifikacji nowych technologii do koszyka, weryfikacji technologii zawartych w koszyku oraz zapewnienia w koszyku najbardziej efektywnych technologii.

Schemat i składowe procesu oceny technologii medycznych w ramach AOTMiT przedstawia Rysunek 2.

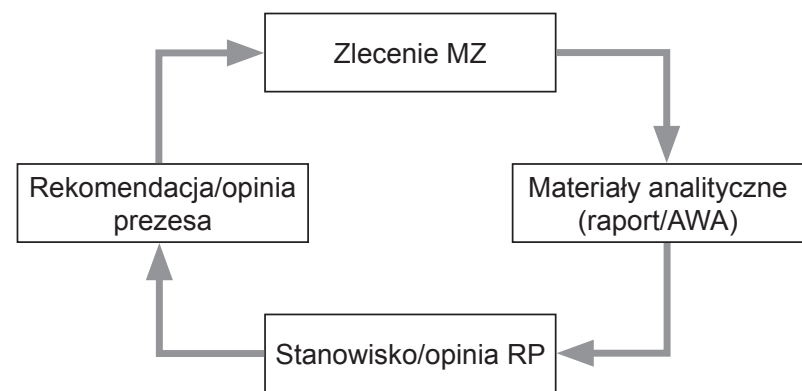

Rysunek 2. Schemat procesu oceny technologii medycznych Źródto: Opracowanie własne AOTMiT.

W ramach publikacji przedstawiono w sposób szczegółowy opis zadań realizowanych przez agencję na podstawie ustawy o świadczeniach i ustawy o refundacji.

\section{Kwalifikowanie świadczeń opieki zdrowotnej jako świad- czeń gwarantowanych}

Podstawą do wydania rekomendacji dla danego świadczenia jest otrzymanie zlecenia ministra właściwego do spraw zdrowia w sprawie kwalifikacji danego świadczenia jako świadczenia gwarantowanego wraz z określeniem poziomu finansowania w sposób kwotowy albo procentowy lub sposobu jego finansowania. Powyższe zlecenie zawiera opis świadczenia opieki zdrowotnej 
wraz z opisem choroby i stanu zdrowia, w których jest udzielane, i jego wpływu na poprawę zdrowia obywateli.

Po otrzymaniu zlecenia prezes AOTMiT zasięga opinii konsultantów krajowych z dziedziny medycyny odpowiedniej dla danego świadczenia opieki zdrowotnej oraz prezesa NFZ w zakresie skutków finansowych dla systemu ochrony zdrowia.

Kolejnym etapem procesu wydania rekomendacji prezesa AOTMiT jest przygotowanie raportu analitycznego uwzględniającego także opinie konsultantów krajowych oraz opinię prezesa NFZ. Powyższy raport jest przedstawiany RP, która na jego podstawie wydaje stanowisko pozytywne lub negatywne w sprawie kwalifikacji danego świadczenia.

Prezes AOTMiT po zasięgnięciu opinii RP wydaje rekomendację, która podobnie jak stanowisko Rady Przejrzystości może być pozytywna lub negatywna. Należy podkreślić, że prezes AOTMiT może wydać rekomendację pozostającą w zgodności bądź w sprzeczności ze stanowiskiem RP. Rekomendacja oparta jest na analizie skuteczności klinicznej, bezpieczeństwa stosowania, stosunku kosztów do uzyskania efektów zdrowotnych ocenianego świadczenia, a także wpływu wprowadzenia ocenianego świadczenia na budżet płatnika.

Rekomendacja w sprawie zakwalifikowania danego świadczenia opieki zdrowotnej jako świadczenia gwarantowanego wraz z określeniem poziomu lub sposobu jego finansowania lub rekomendacja w sprawie niezasadności zakwalifikowania danego świadczenia opieki zdrowotnej jako świadczenia gwarantowanego zostaje niezwłocznie przekazana ministrowi właściwemu do spraw zdrowia oraz zamieszczona w Biuletynie Informacji Publicznej AOTMiT.

Usunięcie świadczenia z koszyka świadczeń gwarantowanych lub zmiana technologii medycznych

Minister zdrowia może dokonać zmiany technologii medycznych, działając $\mathrm{z}$ urzędu, natomiast w przypadku usunięcia danego świadczenia opieki zdrowotnej z wykazu świadczeń gwarantowanych albo dokonania zmiany poziomu lub sposobu finansowania, lub warunków realizacji świadczenia gwarantowanego, działając z urzędu lub na wniosek złożony przez podmioty uprawnione (zgodnie z art. 31e ust. 2 ust. o św. - konsultantów krajowych, stowarzyszenia będące zgodnie z postanowieniami ich statutów towarzystwami naukowymi o zasięgu krajowym - za pośrednictwem konsultantów, prezesa NFZ, stowarzyszenia i fundacje, których celem statutowym jest ochrona praw pacjenta - za pośrednictwem konsultantów). Podobnie jak decyzja o kwalifikacji danego świadczenia jako gwarantowanego, tak i powyższe decyzje następują po uzyskaniu rekomendacji prezesa AOTMiT.

Minister zdrowia w związku z zainicjowaniem postępowania dotyczącego usunięcia świadczenia z koszyka świadczeń gwarantowanych lub jego modyfikacji zleca prezesowi AOTMiT przygotowanie rekomendacji, wyznaczając termin jej przygotowania, o czym niezwłocznie informuje podmiot, który złożył wniosek. $\mathrm{Na}$ podstawie powyższego zlecenia prezes AOTMiT przygotowuje zgodnie ze zleceniem raport pełny albo skrócony w sprawie usunięcia danego świadczenia opieki zdrowotnej z wykazu świadczeń gwarantowanych albo zmiany poziomu lub sposobu finansowania świadczenia gwarantowanego. Prezes AOTMiT niezwłocznie przekazuje raport RP w sprawie oceny świadczenia opieki zdrowotnej. Następnie rada przygotowuje dla prezesa AOTMiT swoje stanowisko, które z kolei jest podstawa do wydania rekomendacji. Prezes AOTMiT niezwłocznie przekazuje rekomendację ministrowi właściwemu do spraw zdrowia oraz podmiotowi, który złożył wniosek, i zamieszcza ją w Biuletynie Informacji Publicznej AOTMiT. Schemat procesu opiniowania w sprawie zasadności usunięcia świadczenia gwarantowanego lub zmiany technologii medycznej przestawia Rysunek 3.

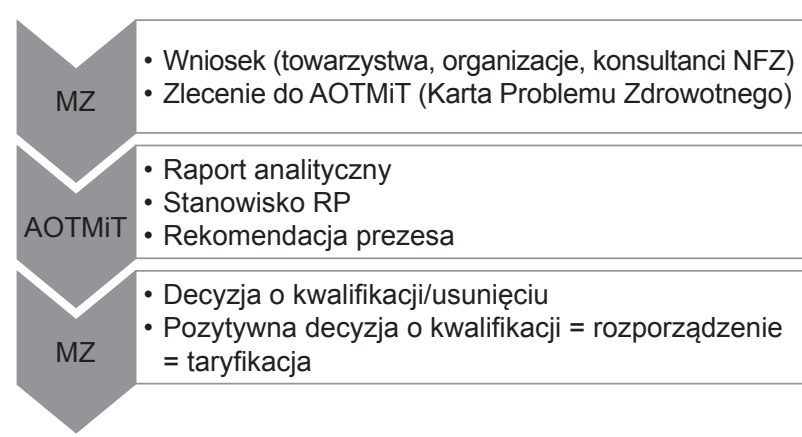

Rysunek 3. Schemat procesu opiniowania w sprawie zasadności kwalifikacji/usunięcia świadczenia gwarantowanego

Źródto: Opracowanie własne AOTMiT.

W zakresie zmiany technologii medycznych planuje się przeprowadzenie gruntownego przeglądu koszyka świadczeń gwarantowanych przy wykorzystaniu narzędzi HTA (ponowna ocena, ang. reassessment). Celem wyżej wymienionych działań jest poprawa jakości realizowanych świadczeń, zapewnienie dostępności do świadczeń, uzyskanie efektu zdrowotnego oraz unikanie strat.

\section{Objęcie refundacją i ustalenie urzędowej ceny zbytu leku, ŚSSPŻ}

$\mathrm{W}$ ramach wniosku refundacyjnego podmiot odpowiedzialny składa uzasadnienie wniosku zawierające między innymi: analizę kliniczną, analizę ekonomiczną, analizę wpływu na budżet podmiotu zobowiązanego do finansowania świadczeń ze środków publicznych, analizę racjonalizacyjną, przedkładaną $\mathrm{w}$ przypadku gdy analiza wpływu na budżet podmiotu zobowiązanego do finansowania świadczeń ze środków publicznych wykazuje wzrost kosztów refundacji.

Powyższe analizy są przekazywane wraz z wnioskiem przez ministra zdrowia prezesowi AOTMiT na podstawie art. 35 ust 1 . ustawy z dnia 12 maja 2011 roku o refundacji leków, środków spożywczych specjalnego przeznaczenia żywieniowego oraz wyrobów medycznych (Dz.U. z 2017 roku poz. 1844 z późn. zm.). 
Pierwszym etapem prac AOTMiT jest ocena przekazanych analiz, z której wyłania się analiza weryfikacyjna [4]. W sytuacji gdy przedłożone dokumenty nie spełniają wymagań określonych w Rozporządzeniu Ministra Zdrowia z dnia 2 kwietnia 2012 roku (Dz.U. z 2012 roku poz. 388) [5], prezes AOTMiT wzywa wnioskodawcę do uzupełnienia analiz.

Przygotowana analiza weryfikacyjna jest przekazywana RP oraz wnioskodawcy. Dodatkowo jest też ona umieszczana w Biuletynie Informacji Publicznej AOTMiT i przez okres siedmiu dni każdy może zgłosić do niej uwagi.

RP po zapoznaniu się z analizą weryfikacyjną wydaje stanowisko odnoszące się do zasadności finansowania ze środków publicznych leku lub ŚSSPŻ.

Prezes AOTMiT, biorąc pod uwagę stanowisko RP, analizę weryfikacyjną oraz złożony wniosek refundacyjny, przygotowuje rekomendację, która zgodnie z art. 35 ust. 6. pkt 3 Ustawy z dnia 12 maja 2011 roku o refundacji leków, środków spożywczych specjalnego przeznaczenia żywieniowego oraz wyrobów medycznych (Dz.U. z 2017 roku poz. 1844 z późn. zm.) zawiera w szczególności: wskazanie dowodów naukowych, na podstawie których została wydana rekomendacja, wskazanie technologii alternatywnych; omówienie wpływu na wydatki podmiotu zobowiązanego do finansowania świadczeń ze środków publicznych i świadczeniobiorców; wskazanie i omówienie rekomendacji klinicznych oraz refundacyjnych; wskazanie wartości progowej ceny zbytu netto, przy której stosunek kosztów do uzyskiwanych efektów zdrowotnych nie jest większy od progu kosztu uzyskania dodatkowego roku życia skorygowanego o jakość; wskazanie, czy zachodzą okoliczności, o których mowa w art. 13 ust. 3, oraz maksymalnego poziomu ceny ustalonego zgodnie $\mathrm{z}$ art. 13 ust. 4. Schemat procesu wydawania rekomendacji $\mathrm{w}$ sprawie objęcia refundacją i ustalenia urzędowej ceny zbytu leku, ŚSSPŻ przedstawia Rysunek 4.

Należy podkreślić, że prezes AOTMiT może wydać rekomendację pozostającą w zgodności bądź w sprzeczności ze stanowiskiem RP.

Przygotowana rekomendacja w sprawie objęcia refundacją i ustalenie urzędowej ceny zbytu leku, ŚSSPŻ zostaje niezwłocznie przekazana ministrowi zdrowia oraz umieszczona w Biuletynie Informacji Publicznej AOTMiT.

\section{Import docelowy}

W przypadku leku nieposiadającego pozwolenia na dopuszczenie do obrotu lub niedostępnego w obrocie na terytorium Rzeczypospolitej Polskiej i sprowadzanego $\mathrm{z}$ zagranicy na warunkach $\mathrm{i} \mathrm{w}$ trybie określonych w art. 4 Ustawy z dnia 6 września 2001 roku Prawo farmaceutyczne oraz ŚSSPŻ, o którym mowa w art. 29a Ustawy z dnia 25 sierpnia 2006 roku o bezpieczeństwie żywności i żywienia, świadczeniobiorca może złożyć wniosek o refundację wyżej wymienionych produktów. Minister właściwy do spraw zdrowia rozpatruje przedmiotowy wniosek o refundację $\mathrm{w}$ terminie nie dłuższym niż 30 dni od dnia wystąpienia o ich refundację przez

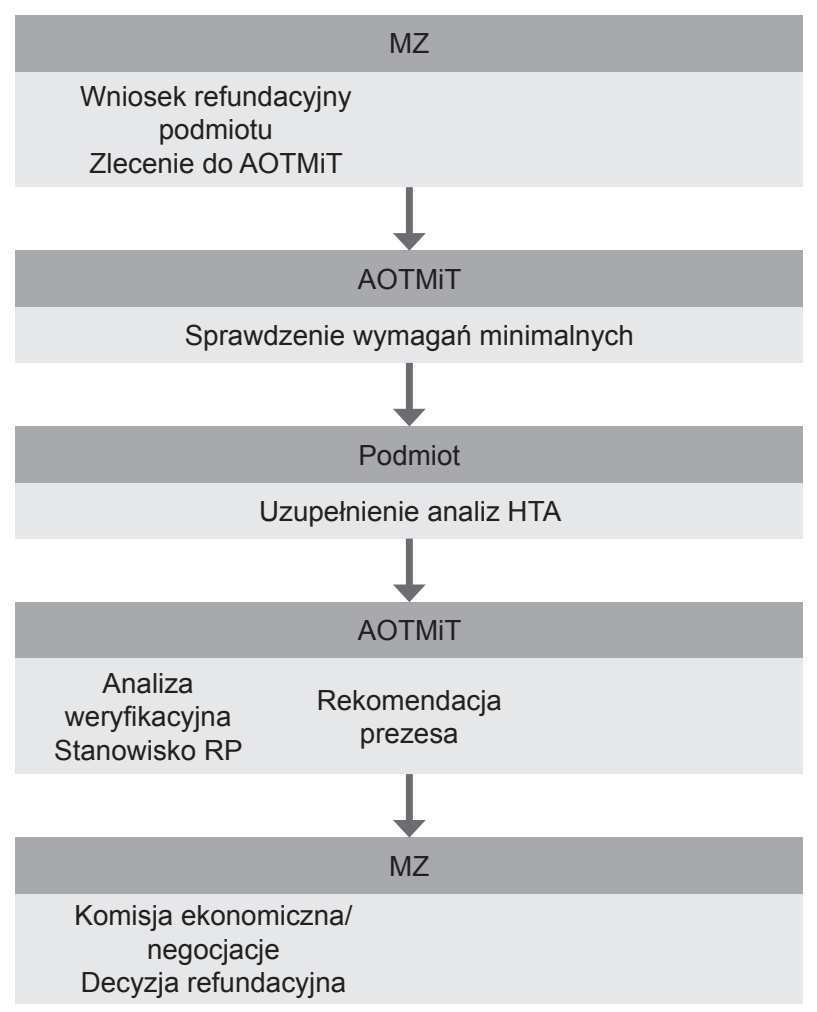

Rysunek 4. Schemat procesu oceny w sprawie objęcia refundacja i ustalenie urzędowej ceny zbytu leku, środka spożywczego specjalnego przeznaczenia żywieniowego

Źródto: Opracowanie własne AOTMiT.

świadczeniobiorcę. W przypadku wydania zgody na refundację tego leku lub ŚSSPŻ przez ministra właściwego do spraw zdrowia mogą one być wydawane po wniesieniu przez świadczeniobiorcę opłaty ryczałtowej za opakowanie jednostkowe.

W celu zbadania zasadności wydawania zgody na refundację leku nieposiadającego pozwolenia na dopuszczenie do obrotu lub niedostępnego $\mathrm{w}$ obrocie na terytorium Rzeczypospolitej Polskiej i sprowadzanego z zagranicy na warunkach i w trybie określonych $\mathrm{w}$ art. 4 Ustawy z dnia 6 września 2001 roku Prawo farmaceutyczne oraz środka spożywczego specjalnego przeznaczenia żywieniowego, o którym mowa w art. 29a Ustawy z dnia 25 sierpnia 2006 roku o bezpieczeństwie żywności i żywienia, minister właściwy do spraw zdrowia może wystąpić do prezesa AOTMiT o wydanie rekomendacji w sprawie zasadności refundacji tego leku lub ŚSSPŻ w określonym wskazaniu. Schemat procesu wydawania rekomendacji w sprawie zasadności wydawania zgody na refundację leku sprowadzanego w ramach importu docelowego przestawia Rysunek 5.

W przypadku wystąpienia ministra właściwego do spraw zdrowia do prezesa AOTMiT o wydanie rekomendacji, o której mowa w ust. 3, bieg terminu na rozpatrzenie sprawy ulega zawieszeniu do dnia otrzymania przez ministra właściwego do spraw zdrowia tej rekomendacji. Rekomendacja jest ważna przez okres trzech lat i ma zastosowanie również do innych leków zawierających tę samą substancję czynną oraz zbliżoną 


\begin{tabular}{|l|l|}
\hline MZ & $\begin{array}{l}\text { - Wniosek o import i finansowanie (świadczeniobiorca) } \\
\text { - Przekazanie zlecenia do AOTMiT }\end{array}$ \\
\hline - Raport analityczny \\
AOTMiT
\end{tabular}

Rysunek 5. Schemat procesu wydawania rekomendacji $w$ sprawie finansowania leku sprowadzanego w ramach importu docelowego

Źródto: Opracowanie własne AOTMiT.

postać farmaceutyczną, a także do ŚSSPŻ o składzie identycznym z ocenianym środkiem. W przypadku leku posiadającego dopuszczenie do obrotu na terytorium Rzeczypospolitej Polskiej, a niedostępnego w obrocie na terytorium Rzeczypospolitej Polskiej, zgoda może być wydawana na okres nie dłuższy niż jeden rok, licząc od dnia wpłynięcia pierwszego wniosku dla danego leku lub ŚSSPŻ. Powyższe nie dotyczy sytuacji kontynuacji leczenia finansowanego dotychczas ze środków publicznych danym lekiem lub ŚSSPŻ w określonym wskazaniu u danego pacjenta.

Przygotowana rekomendacja zostaje niezwłocznie przekazana ministrowi zdrowia oraz umieszczona w Biuletynie Informacji Publicznej AOTMiT.

Minister właściwy do spraw zdrowia odmawia wydania zgody w odniesieniu do leku lub ŚSSPŻ w danym wskazaniu, w przypadku gdy z rekomendacji wynika, że nie jest zasadne ich finansowanie ze środków publicznych w tym wskazaniu lub została wydana rekomendacja, o której mowa w art. $35 \mathrm{w}$ odniesieniu do substancji czynnej zawartej w tym leku albo w odniesieniu do tego ŚSSPŻ w tym wskazaniu.

\section{Ratunkowy dostęp do technologii lekowych}

W sytuacji zagrożenia życia lub zdrowia pacjenta oraz gdy zostały wykorzystane wszystkie możliwe do zastosowania w danym wskazaniu finansowane ze środków publicznych technologie medyczne, a jest dostępny na rynku lek, którego zastosowanie ma uzasadnienie zgodnie $\mathrm{z}$ aktualną wiedzą medyczną, minister zdrowia może wydać zgodę na pokrycie kosztów tego produktu leczniczego $\mathrm{w}$ ramach ratunkowego dostępu do technologii lekowej na podstawie art. 47d Ustawy z dnia 27 sierpnia 2004 roku o świadczeniach opieki zdrowotnej finansowanych ze środków publicznych (Dz.U. z 2018 roku poz. 1510 z późn. zm.). Zgoda ta jest wydawana na okres nie dłuższy niż trzy miesiące leczenia lub też trzy cykle terapii.

Wniosek o ratunkowy dostęp do technologii lekowych składa świadczeniodawca w imieniu świadczeniobiorcy do ministra właściwego do spraw zdrowia. Po ocenie formalnej minister zleca AOTMiT sporządzenie opinii w sprawie zasadności finansowania ze środków publicznych leku w danym wskazaniu. Pierwszym etapem prac AOTMiT jest przygotowanie opracowania w sprawie zasadności finansowania ze środków publicznych odnoszącego się do wnioskowanej technologii, które to jest niezwłocznie przekazywane RP. Rada po zapoznaniu się $\mathrm{z}$ opracowaniem wydaje opinię $\mathrm{w}$ sprawie zasadności finansowania ze środków publicznych odnoszącą się do wnioskowanej technologii. Następnie biorąc pod uwagę opinię RP oraz: istotność stanu klinicznego; skuteczność i bezpieczeństwo stosowania wnioskowanej interwencji, jak też komparatorów, relację korzyści zdrowotnych do ryzyka stosowania; konkurencyjność cenową wnioskowanej interwencji względem możliwych technologii alternatywnych; wpływ na budżet podmiotu zobowiązanego do finansowania świadczeń ze środków publicznych i świadczeniobiorców, prezes AOTMiT sporządza opinię w sprawie zasadności finansowania ze środków publicznych odnoszącą się do wnioskowanej technologii. Podobnie jak w przypadku innych procesów opinia prezesa AOTMiT nie musi pozostawać w zgodności z opinią RP.

Przygotowana opinia w sprawie zasadności finansowania ze środków publicznych leku w ramach ratunkowego dostępu do technologii lekowych zostaje niezwłocznie przekazana ministrowi zdrowia oraz umieszczona w Biuletynie Informacji Publicznej AOTMiT. Schemat procesu opiniowania $\mathrm{w}$ sprawie zasadności finansowania leku w trybie RDTL przestawia Rysunek 6.

W ramach ratunkowego dostępu do technologii le-

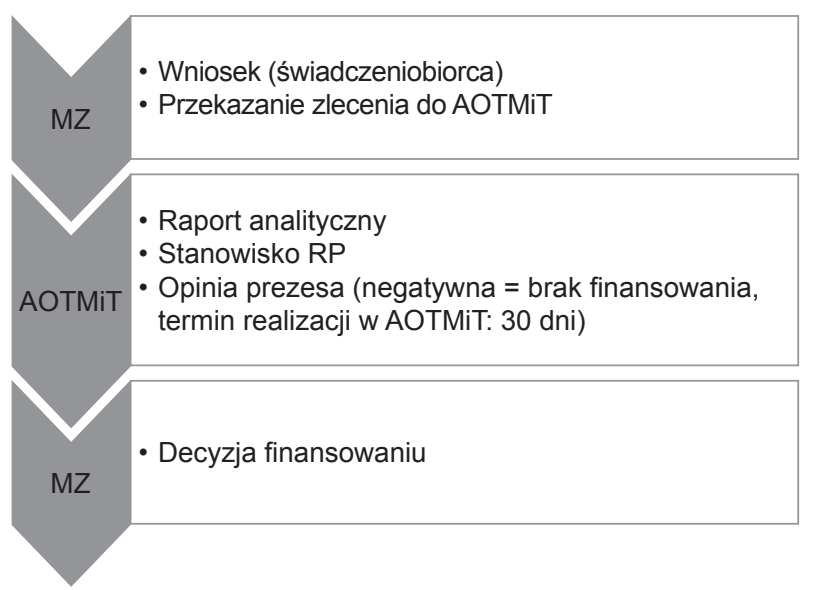

Rysunek 6. Schemat procesu wydawania rekomendacji w sprawie zasadności finansowania technologii medycznych $w$ ramach ratunkowego dostepu do technologii lekowych

Źródto: Opracowanie własne AOTMiT.

kowych podejmowane są indywidualne decyzje kliniczne opierające się na dowodach naukowych. Negatywna opinia prezesa agencji uniemożliwia MZ wydanie zgody na finansowanie technologii we wnioskowanym wskazaniu. Wnioski o ratunkowy dostęp do technologii lekowych są składane w sytuacji niepowodzenia terapii 
innymi technologiami, które są obecnie finansowane $\mathrm{z}$ budżetu państwa.

Objęcie refundacją leku przy danych klinicznych, w zakresie wskazań do stosowania lub dawkowania, lub sposobu podawania odmiennych niż określone w Charakterystyce Produktu Leczniczego (off-label)

Jeżeli jest to niezbędne dla ratowania zdrowia i życia świadczeniobiorców, minister właściwy do spraw zdrowia, po zasięgnięciu opinii RP oraz konsultanta krajowego w odpowiedniej dziedzinie medycyny, może wydać z urzędu, przy uwzględnieniu kryteriów wskazanych w ust. o św. oraz stosunku kosztów do uzyskiwanych efektów zdrowotnych, decyzję administracyjną o objęciu refundacją leku przy danych klinicznych, w zakresie wskazań do stosowania lub dawkowania, lub sposobu podawania odmiennych niż określone w Charakterystyce Produktu Leczniczego w rozumieniu Ustawy z dnia 6 września 2001 roku Prawo farmaceutyczne.

Rada Przejrzystości wydaje opinię w terminie 14 dni, biorąc pod uwagę $\mathrm{w}$ szczególności istotność stanu klinicznego, w którym ma być stosowany lek. Opinie wydawane w odniesieniu do substancji czynnej w określonym wskazaniu są ważne przez okres trzech lat.

$\mathrm{W}$ terminie 30 dni przed upływem terminu obowiązywania poprzedniej opinii RP oraz konsultant krajowy W odpowiedniej dziedzinie medycyny wydają kolejną opinię w odniesieniu do danej substancji czynnej w określonym wskazaniu, chyba że: minister właściwy do spraw zdrowia przekaże prezesowi AOTMiT lub konsultantowi krajowemu w odpowiedniej dziedzinie medycyny informację o zamiarze odstąpienia od refundacji w tym wskazaniu lub dane wskazanie zostanie ujęte w Charakterystyce Produktu Leczniczego. Schemat procesu opiniowania W sprawie zasadności finansowania ze środków publicznych technologii medycznych poza wskazaniami rejestracyjnymi przestawia Rysunek 7.

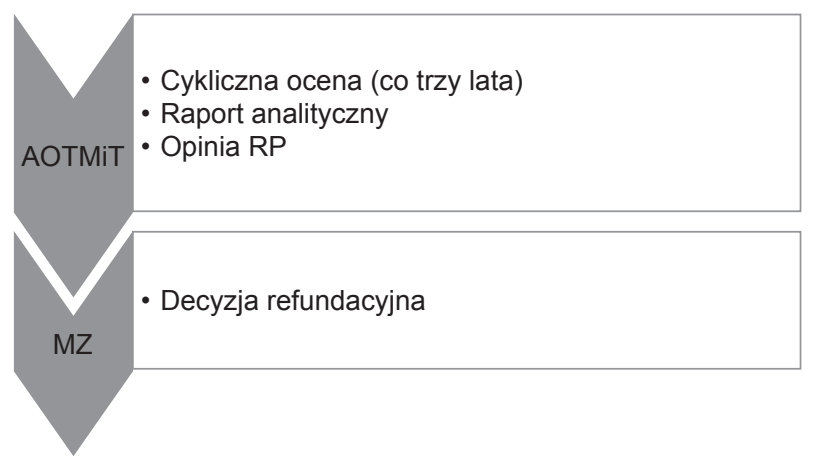

Rysunek 7. Schemat procesu opiniowania off-label Źródto: Opracowanie własne AOTMiT.

Prezes AOTMiT publikuje w Biuletynie Informacji Publicznej AOTMiT opinię RP wraz z określeniem terminu jej ważności łącznie z materiałami, na podstawie których została wydana.
Opiniowanie zaleceń postępowania dotyczących diagnostyki i leczenia w zakresie świadczeń finansowanych ze środków publicznych w zakresie diagnostyki mającej na celu rozpoznanie nowotworu złośliwego lub miejscowo złośliwego i leczenia mającego na celu wyleczenie tego nowotworu

Minister właściwy do spraw zdrowia, po zasięgnięciu opinii agencji, może ogłosić, a w zakresie diagnostyki mającej na celu rozpoznanie nowotworu złośliwego lub miejscowo złośliwego, zwanej dalej „diagnostyką onkologiczną", i leczenia mającego na celu wyleczenie tego nowotworu, zwanego dalej „leczeniem onkologicznym”, ogłasza - w obwieszczeniu - zalecenia postępowania dotyczące diagnostyki i leczenia w zakresie świadczeń finansowanych ze środków publicznych, odrębnie dla poszczególnych dziedzin medycyny, opracowane przez odpowiednie stowarzyszenia będące zgodnie z postanowieniami ich statutów towarzystwami naukowymi o zasięgu krajowym, zrzeszające specjalistów w danej dziedzinie medycyny.

Wprowadzenie regulacji w wyżej wymienionym zakresie ma na celu ułatwienie dostępu do aktualnej wiedzy medycznej i poprawę procesu podejmowania decyzji klinicznych opartych na dowodach naukowych, eliminację nieskutecznych metod leczenia, o nieudowodnionej skuteczności, szkodliwych, jak również umożliwienie opracowania narzędzi oceny jakości świadczonych usług i poprawę tej jakości. Zalecenia postępowania dotyczące diagnostyki i leczenia nowotworów będą stanowiły bazę wiedzy medycznej zgromadzoną w poręcznej, łatwej do wdrożenia formie. Zalecenia mają służyć także promocji dobrej praktyki medycznej, opartej na dowodach naukowych i szerokim konsensusie ekspertów. Zakres wytycznych obejmuje świadczenia finansowane ze środków publicznych. Powyższe działania mają wpływ na optymalizację w zakresie jakości świadczeń zdrowotnych.

\section{Projekty programów polityki zdrowotnej}

Ustawa o świadczeniach opieki zdrowotnej finansowanych ze środków publicznych wskazuje, że programy polityki zdrowotnej (PPZ) mogą opracowywać, wdrażać, realizować i finansować ministrowie oraz jednostki samorządu terytorialnego (JST). PPZ powinny opierać się na mapach potrzeb zdrowotnych oraz dostępnych danych epidemiologicznych. Mogą być realizowane w okresie jednego roku lub wieloletnim. PPZ jest opracowywany według wzoru wydawanego przez właściwego ministra $\mathrm{w}$ formie rozporządzenia. W przypadku gdy projekt PPZ nie został opracowany według wzoru określonego w przepisach, prezes AOTMiT wzywa podmiot, który opracował projekt, do jego poprawienia.

Prezes AOTMiT sporządza opinię dotyczącą PPZ w terminie dwóch miesięcy od dnia otrzymania projektu PPZ lub poprawionego projektu PPZ na podstawie sporządzonego przez AOTMiT raportu. Raport AOTMiT oraz opinia prezesa zostają sporządzone na podstawie kryteriów, o których mowa w ustawie o świadczeniach opieki zdrowotnej finansowanych ze środków publicznych. 
Przed sporządzeniem raportu prezes AOTMiT może zasięgnąć opinii konsultantów w ochronie zdrowia lub innych ekspertów z różnych dziedzin medycyny, w głównej mierze odpowiednich dla danej choroby lub danego problemu zdrowotnego. Na kolejnym etapie prezes AOTMiT przekazuje raport RP w celu sporządzenia przez nią opinii, która następnie jest przekazywana prezesowi AOTMiT. Uwzględniając opinię RP, prezes AOTMiT sporządza opinię, która jest niezwłocznie przekazywana podmiotowi opracowującemu projekt PPZ. Schemat procesu opiniowania PPZ przedstawia Rysunek 8.

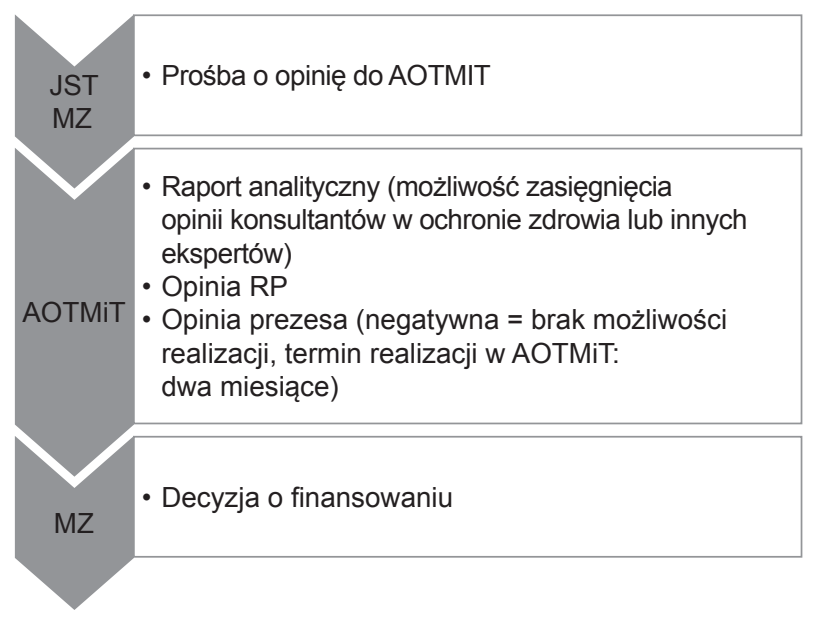

Rysunek 8. Schemat procesu opiniowania programów polityki zdrowotnej

Źródło: Opracowanie własne AOTMiT.

Rozpoczęcie wdrożenia, realizacji i finansowania programu polityki zdrowotnej może nastąpić wyłącznie po uzyskaniu pozytywnej lub warunkowo pozytywnej opinii prezesa AOTMiT. Podmiot, który otrzymał warunkowo pozytywną opinię prezesa AOTMiT, jest obowiązany do wprowadzenia w projekcie PPZ zmian zgodnych z tą opinią przed rozpoczęciem wdrożenia, realizacji i finansowania PPZ. Po zakończeniu jego realizacji minister oraz JST sporządzają $\mathrm{w}$ terminie trzech miesięcy od dnia zakończenia realizacji programu raport końcowy $\mathrm{z}$ realizacji PPZ według wzoru określonego w rozporządzeniu przez właściwego ministra do spraw zdrowia i przekazują go do AOTMiT.

Agencja tworzy repozytorium PPZ, które udostępnia w Biuletynie Informacji Publicznej AOTMiT oraz na swojej stronie internetowej.

Rekomendacje w sprawie zalecanych technologii medycznych, działań przeprowadzanych w ramach PPZ oraz warunków realizacji tych programów, dotyczących danej choroby lub danego problemu zdrowotnego

Agencja, z własnej inicjatywy lub z inicjatywy ministra właściwego do spraw zdrowia, dokonuje okresowej weryfikacji założeń zgromadzonych projektów PPZ i na podstawie tej weryfikacji przygotowuje raport w sprawie zalecanych technologii medycznych, działań przeprowadzanych w ramach PPZ oraz warunków realizacji tych programów dotyczących danej choroby lub danego problemu zdrowotnego.

Raport jest przygotowywany na podstawie kryteriów wskazanych w ust. o św. oraz po zasięgnięciu opinii konsultantów w ochronie zdrowia lub innych ekspertów z poszczególnych dziedzin medycyny, zwłaszcza odpowiednich dla danej choroby lub danego problemu zdrowotnego.

Prezes AOTMiT niezwłocznie przekazuje raport $\mathrm{RP}$, która na jego podstawie wydaje opinię w sprawie zalecanych technologii medycznych, działan przeprowadzanych $\mathrm{w}$ ramach PPZ oraz warunków realizacji tych programów dotyczących danej choroby lub danego problemu zdrowotnego.

Prezes AOTMiT, biorąc pod uwagę opinię RP, wydaje rekomendację $\mathrm{w}$ sprawie zalecanych technologii medycznych, działań przeprowadzanych w ramach PPZ oraz warunków realizacji tych programów dotyczących danej choroby lub danego problemu zdrowotnego. W ust. o św. nie określono ram czasowych dla przedmiotowego procesu.

Opracowanie i wydanie wyżej wymienionej rekomendacji dotyczącej danej choroby lub danego problemu zdrowotnego może także zlecić prezesowi AOTMiT minister właściwy do spraw zdrowia. W tym przypadku prezes AOTMiT wydaje rekomendację w terminie czterech miesięcy od dnia otrzymania zlecenia.

Rekomendacje prezesa wydawane $\mathrm{z}$ inicjatywy AOTMiT lub na zlecenie ministra właściwego do spraw zdrowia zawierają: opis choroby lub problemu zdrowotnego uwzględniający epidemiologię; rekomendowane i nierekomendowane technologie medyczne, działania przeprowadzane $\mathrm{w}$ ramach programów polityki zdrowotnej skierowane do określonej populacji docelowej oraz warunki realizacji PPZ dotyczące danej choroby lub danego problemu zdrowotnego; wskazanie dowodów naukowych; wskazanie opcjonalnych technologii medycznych i aktualnego stanu ich finansowania ze środków publicznych na terytorium Rzeczypospolitej Polskiej; określenie wskaźników służących do monitorowania i ewaluacji. Rekomendacje podlegają aktualizacji nie rzadziej niż co pięć lat.

Od dnia udostępnienia rekomendacji w Biuletynie Informacji Publicznej AOTMiT minister oraz JST uwzględniają zawarte $\mathrm{w}$ niej zalecenia $\mathrm{w}$ planowanych PPZ. Podmiot, który opracował projekt PPZ uwzględniający rekomendację, przed rozpoczęciem wdrożenia, realizacji i finansowania PPZ przesyła do AOTMiT oświadczenie o zgodności projektu PPZ z tą rekomendacją. Schemat procesu wydawania rekomendacji w tym trybie przestawia Rysunek 9.

Wydawanie rekomendacji dla problemów zdrowotnych umożliwi przygotowanie modelowych PPZ bez konieczności opiniowania ich przez AOTMiT oraz wskazanie rekomendowanych interwencji o potwierdzonej skuteczności i bezpieczeństwie $\mathrm{w}$ określonych populacjach. Zbieranie danych o PPZ realizowanych w Polsce i ich rezultatach ma na celu uzyskanie pełnego obrazu działań na rzecz zdrowia publicznego. 


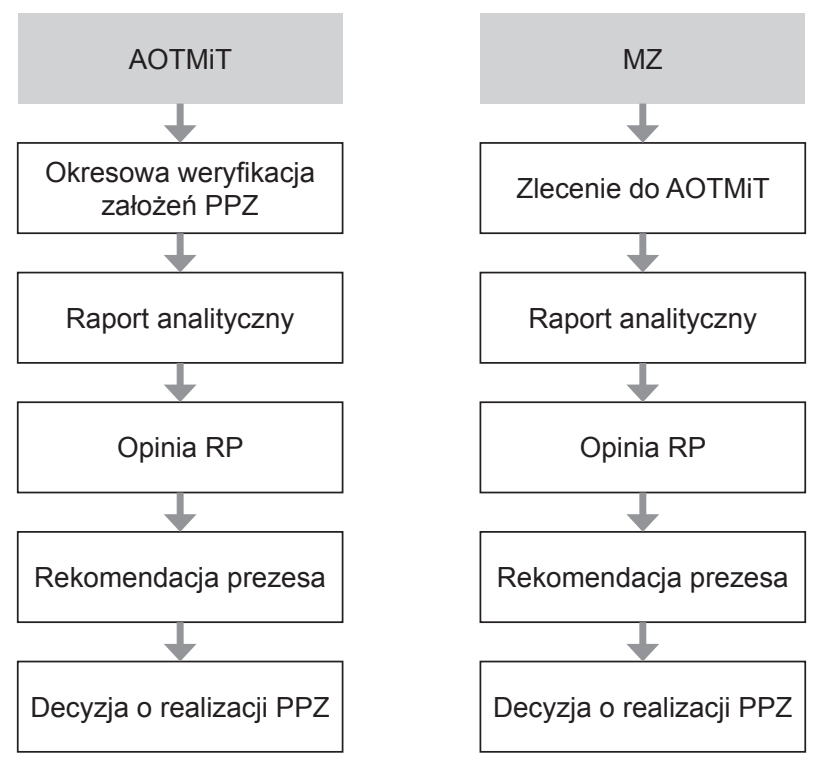

Rysunek 9. Schemat procesu wydania rekomendacji w sprawie zalecanych technologii medycznych, działań przeprowadzanych w ramach programów polityki zdrowotnej oraz warunków realizacji tych programów dotyczacych danej choroby lub danego problemu zdrowotnego

Źródto: Opracowanie własne AOTMiT.

\section{Taryfikacja świadczeń opieki zdrowotnej}

Do zadań AOTMiT związanych $\mathrm{z}$ taryfikowaniem świadczeń należą: ustalanie taryfy świadczeń; opracowywanie propozycji zaleceń dotyczących standardu rachunku kosztów; opracowywanie, weryfikacja, gromadzenie, udostępnianie i upowszechnianie informacji o metodologii oraz zasadach ustalania taryfy świadczeń.

Taryfa świadczeń jest zestawieniem wartości względnych wyrażonych w punktach, stosowanym w rozliczeniach między płatnikiem a świadczeniodawcą. Taryfikowane mogą być świadczenia gwarantowane, czyli wpisane do koszyka.

Taryfikacja świadczeń opieki zdrowotnej jest prowadzona na podstawie planu taryfikacji AOTMiT sporządzanego na rok kalendarzowy w terminie do 1 czerwca roku poprzedzającego rok, którego dotyczy ten plan. Kolejność świadczeń opieki zdrowotnej podlegających taryfikacji wynika z planu taryfikacji zatwierdzonego przez ministra zdrowia. Projekt planu taryfikacji AOTMiT jest przekazywany do zaopiniowania prezesowi NFZ oraz Radzie do spraw Taryfikacji. Prezes AOTMiT przesyła ministrowi właściwemu do spraw zdrowia plan taryfikacji AOTMiT wraz z opinią prezesa Funduszu i Rady do spraw Taryfikacji do zatwierdzenia w terminie do 16 czerwca roku poprzedzającego rok, którego dotyczy ten plan. Minister właściwy do spraw zdrowia może zalecić wprowadzenie zmian w planie taryfikacji AOTMiT, określając termin ich wprowadzenia nie dłuższy niż siedem dni. W przypadku nieprzedstawienia planu taryfikacji $\mathrm{w}$ terminie, niewprowadzenia $w$ nim przez AOTMiT zmian albo niezatwierdzenia planu minister właściwy do spraw zdrowia sporządza plan taryfikacji AOTMiT. W szczególnie uzasadnionych przypadkach minister właściwy do spraw zdrowia po zasięgnięciu opinii prezesa AOTMiT zmienia plan taryfikacji AOTMiT.

Prezes AOTMiT określa taryfę świadczeń w danym zakresie lub rodzaju po dokonaniu przez AOTMiT analizy określonych danych lub na podstawie innych dostępnych danych niezbędnych do ustalenia taryfy świadczeń oraz publikuje ją w formie obwieszczenia w Biuletynie Informacji Publicznej AOTMiT po jej zatwierdzeniu przez ministra właściwego do spraw zdrowia.

Przed określeniem taryfy świadczeń w danym zakresie lub rodzaju prezes AOTMiT przygotowuje raport w sprawie ustalenia taryfy świadczeń oraz zwraca się do Rady do spraw Taryfikacji o wydanie stanowiska w sprawie ustalenia taryfy świadczeń. Raport w sprawie ustalenia taryfy świadczeń zawiera: opis świadczenia opieki zdrowotnej podlegającego taryfikacji ze szczególnym uwzględnieniem wpływu świadczenia opieki zdrowotnej na stan zdrowia obywateli, w tym zapadalności, chorobowości, umieralności lub śmiertelności, skutków następstw choroby lub stanu zdrowia; analizę popytu oraz aktualnej i pożądanej podaży świadczenia opieki zdrowotnej podlegającego taryfikacji; opis sposobu i poziomu finansowania świadczenia opieki zdrowotnej podlegającego taryfikacji w innych krajach; analizę danych kosztowych pozyskanych od świadczeniodawców, jeżeli miały wpływ na ustalenie taryfy świadczeń; projekt taryfy świadczeń; analizę skutków finansowych dla systemu ochrony zdrowia, w tym dla podmiotów zobowiązanych do finansowania świadczeń opieki zdrowotnej ze środków publicznych oraz inne dostępne dane niezbędne do ustalenia taryfy świadczeń. Prezes AOTMiT publikuje raport w sprawie ustalenia taryfy świadczeń w Biuletynie Informacji Publicznej AOTMiT. Do raportu w sprawie ustalenia taryfy świadczeń można zgłaszać uwagi w terminie siedmiu dni od dnia jego opublikowania, które są zamieszczane w Biuletynie Informacji Publicznej AOTMiT.

Przed wydaniem stanowiska w sprawie ustalenia taryfy świadczeń Rada do spraw Taryfikacji może prowadzić na posiedzeniu konsultacje w sprawie taryfy z: konsultantem krajowym w dziedzinie medycyny związanej ze świadczeniem opieki zdrowotnej podlegającym taryfikacji, przedstawicielami ogólnopolskich towarzystw naukowych w dziedzinie medycyny związanej ze świadczeniem opieki zdrowotnej podlegającym taryfikacji, przedstawicielami organizacji świadczeniodawców, przedstawicielami organizacji społecznych działających na rzecz praw pacjentów oraz innymi podmiotami lub osobami, których udział w konsultacjach jest istotny w ocenie Rady do spraw Taryfikacji dla ustalenia taryfy świadczeń.

Rada do spraw Taryfikacji na podstawie raportu w sprawie ustalenia taryfy świadczeń, zgłoszonych uwag oraz - w przypadku przeprowadzenia konsultacji - ustaleń podjętych w ich trakcie wydaje stanowisko w sprawie ustalenia taryfy świadczeń w terminie 30 dni od dnia otrzymania raportu w sprawie ustalenia taryfy świadczeń. Stanowisko Rady do spraw Taryfikacji w sprawie ustalenia taryfy świadczeń jest publikowane w Biuletynie Informacji Publicznej AOTMiT. 
Prezes AOTMiT, biorąc pod uwagę raport w sprawie ustalenia taryfy świadczeń oraz stanowisko Rady do spraw Taryfikacji w sprawie ustalenia taryfy świadczeń, określa taryfę świadczeń, a nastepnie przesyła niezwłocznie projekt obwieszczenia zawierającego określenie taryfy świadczeń, raport w sprawie ustalenia taryfy świadczeń i stanowisko Rady do spraw Taryfikacji w sprawie ustalenia taryfy świadczeń do ministra właściwego do spraw zdrowia.

Minister właściwy do spraw zdrowia po zapoznaniu się z taryfą świadczeń, raportem w sprawie ustalenia taryfy świadczeń i stanowiskiem Rady do spraw Taryfikacji zatwierdza lub w szczególnie uzasadnionych przypadkach, mając na uwadze określone dane lub inne dostępne dane niezbędne do ustalenia taryfy świadczeń, zmienia taryfę świadczeń określoną przez prezesa AOTMiT oraz przekazuje ją prezesowi AOTMiT w celu opublikowania w formie obwieszczenia w Biuletynie Informacji Publicznej AOTMiT. Skrócony schemat procesu taryfikacji świadczeń gwarantowanych przedstawia Rysunek 10.

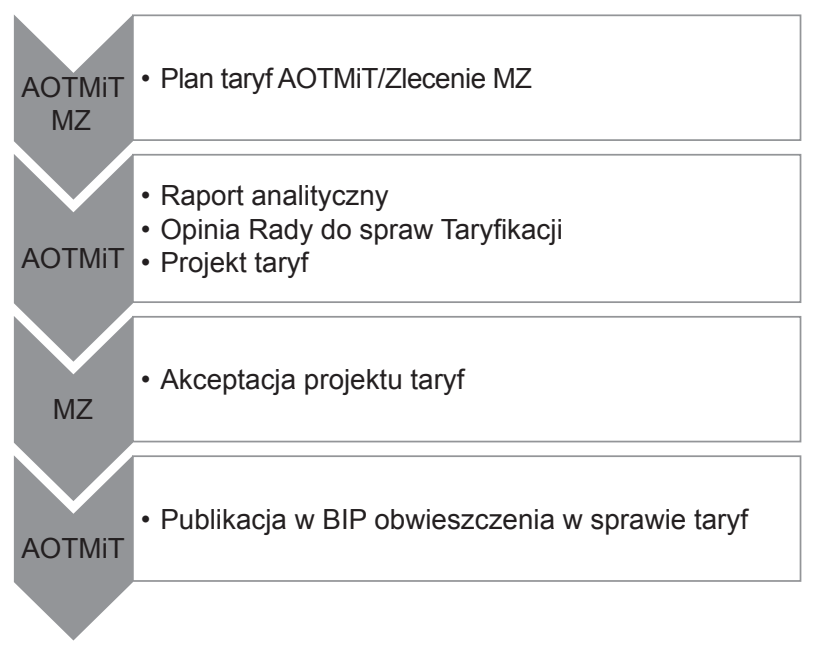

Rysunek 10. Skrócony schemat procesu taryfikacji świadczeń gwarantowanych

Źródło: Opracowanie własne AOTMiT.

W celu pozyskania danych niezbędnych do ustalenia taryfy agencja zawiera umowy z podmiotami, które zapewniają najwyższą jakość i kompletność przekazywanych danych oraz zostały wyłonione w postępowaniu ogłoszonym przez AOTMiT. Podmioty zobowiązane do finansowania świadczeń opieki zdrowotnej ze środków publicznych udostępniają nieodpłatnie AOTMiT dane konieczne do określenia taryfy świadczeń. Współpraca $\mathrm{z}$ agencją jest dobrowolna, ale jak największa ilość danych od jak największej liczby świadczeniodawców jest gwarantem rzetelnie przeprowadzonych analiz. Agencja jest obowiązana do przekazywania danych udostępnianych przez świadczeniodawców ministrowi właściwemu do spraw zdrowia na jego wniosek.

Minister właściwy do spraw zdrowia określa w formie rozporządzenia zalecenia dotyczące standardu rachunku kosztów u świadczeniodawców, kierując się potrzebą ujednolicenia sposobu identyfikowania, gromadzenia, przetwarzania, prezentowania i interpretowania informacji o kosztach świadczeń opieki zdrowotnej.

\section{Podsumowanie}

Opieka zdrowotna wysokiej jakości to taka, w której zasoby medyczne, kadrowe, infrastrukturalne i finansowe są zorganizowane w możliwie najbardziej efektywny sposób. Oznacza to działania mające na celu zaspokojenie potrzeby społeczeństwa w zakresie profilaktyki, promocji zdrowia, diagnostyki, leczenia i rehabilitacji oraz pewność, że opieka ta spełnia wymagania bezpieczeństwa, skuteczności i efektywności. Działalność AOTMiT w zakresie oceny technologii medycznych i taryfikacji świadczeń gwarantowanych wpisuje się w system ochrony zdrowia, którego jednym z celów jest zapewnienie skutecznej i zgodnej ze standardami jakości opieki zdrowotnej.

\section{Piśmiennictwo}

\section{Akty prawne i dokumenty}

1. Ustawa z dnia 27 sierpnia 2004 roku o świadczeniach opieki zdrowotnej finansowanych ze środków publicznych (Dz.U. z 2018 roku poz. 1510 z późn. zm.).

2. Ustawa z dnia 12 maja 2011 roku o refundacji leków, środków spożywczych specjalnego przeznaczenia żywieniowego oraz wyrobów medycznych (Dz.U. z 2017 roku poz. 1844 z późn. zm.).

3. Wytyczne przeprowadzania Oceny Technologii Medycznych (HTA). Załącznik do Zarządzenia nr 40/2016 Prezesa AOTMiT Oceny Technologii Medycznych i Taryfikacji z dnia 13 września 2016 roku w sprawie wytycznych oceny świadczeń opieki zdrowotnej, http://www.aotm.gov.pl/ www/wp-content/uploads/wytyczne_hta/2016/20160913 Wytyczne_AOTMiT.pdf (dostęp: 18.01.2019 r.).

4. Rozporządzenie Ministra Zdrowia z dnia 18 grudnia 2013 roku w sprawie sposobu i procedur przygotowania analizy weryfikacyjnej AOTMiT Oceny Technologii Medycznych oraz wysokości opłaty za tę analizę (Dz.U. z 2014 roku poz. 4).

5. Rozporządzenie Ministra Zdrowia z dnia 2 kwietnia 2012 roku w sprawie minimalnych wymagań, jakie muszą spełniać analizy uwzględnione we wnioskach o objęcie refundacją i ustalenie urzędowej ceny zbytu oraz podwyższenie urzędowej ceny zbytu leku, środka spożywczego specjalnego przeznaczenia żywieniowego, wyrobu medycznego, które nie mają odpowiednika refundowanego w danym wskazaniu (Dz.U. z 2012 roku poz. 388).

6. Opracowania i dokumenty własne AOTMiT. 